\title{
Privatisering av sjukvård: politisk lösning eller komplikation?
}

\author{
PAULA BLOMQVIST
}

\begin{abstract}
Privatiseringar har i debatten ofta framställts som en lösning på sjukvårdens problem, både i Sverige och många andra länder. I artikeln visas att privatiseringens praktik - eleganta teoretiska modeller till trots - ofta är svår och politiskt motsägelsefull. Paradoxalt nog verkar privatisering inom vårdens område också kräva en utvecklad statsmakt.
\end{abstract}

I snart två decennium har privatisering stått i centrum för diskussioner om förnyelsen av sjukvården, både i Sverige och utomlands. De flesta svenska partier, inklusive socialdemokraterna, har haft en uttalat positiv syn på ökningen av andelen privata vårdgivare, även om politisk oenighet har funnits $i$ regleringsfrågor. ${ }^{1}$ Även $i$ andra delar av världen har politiska ledare och experter kommit att se privatisering som ett medel för att effektivisera produktionen av sjukvård och öka patienternas tillfredsställelse. Ett närliggande exempel är

Paula Blomqvist är forskare vid Statsvetenskapliga institutionen, Uppsala Universitet och Arbetslivsinstitutet, Stockholm.
Östeuropa, där försöken att modernisera sjukvården efter 1989 till stor del kommit att handla om privatisering.

Trots detta har ökningen av andelen privata vårdgivare gått påfallande långsamt $i$ de flesta länder. Andelen privat producerad sjukvård inom EU är endast marginellt högre idag än för 20 år sedan. Vare sig inre marknadens fullbordan, EUs konkurrenslagstiftning eller en stadigt växande efterfrågan på vårdtjänster från befolkningens sida tycks ha stimulerat utvecklingen. I Sverige uppgår den andel av vården som

1 Det mest påtagliga exemplet är försäljningen av akutsjukhus till vinstsyftande vårdgivare, som hejdades genom den s.k. Stopplagen 2000. 
bedrivs i privat regi ännu knappt till 10 procent. I stället utmärks utvecklingen av en påfallande politisk osäkerhet, där signalerna till privata vårdgivare ständigt skiftar. I Östeuropa har privatiseringen av de tidigare sovjetiska sjukvårdssystemen snarast stannat upp under senare år och den politiska entusiasmen för privatiseringar tycks ha svalnat betydligt.

Hur kan denna omsvängning i synen på privatiseringar förklaras? Och varför har andelen privata vårdgivare vuxit så långsamt, även under perioder när starkt politiskt stöd för en sådan utveckling funnits? I denna artikel hävdas att åtminstone en del av svaret bör sökas i den komplexitet och delvis motsägelsefulla politiska logik som präglar privatiseringar inom sjukvården. Jag visar att privatisering av vårdproduktion inom ett offentligt finansierat system inte handlar i första hand om att sälja ut produktionsenheter eller tillåta nyetableringar av privata företag, utan om att utveckla och anpassa offentliga regelsystem. Annars blir resultatet ofta det ansvariga politiker minst av allt önskar, nämligen kostnadsökningar och förlorad kontroll över resursfördelningen. Syftet med artikeln är att teoretiskt och empiriskt åskådliggöra detta förhållande genom att först beskriva de idéer som legat till grund för privatiseringssträvandena inom sjukvården och därefter belysa försöken att tillämpa dem i tre inbördes ganska olika länder; Sverige, Tjeckien och Polen.

I artikelns inledande avsnitt ges en introduktion till begreppet "privatisering" och hur det kommit att tillämpas inom sjukvårdens område. Därefter beskrivs de idéer om konkurrens och privatiseringar inom ramen för offentlig finansierade sjukvårdssystem som kom att få genomslag i sjukvårdsdebatten i många länder under 1990-talet. Den följande översikten av hur samma idéer inspirerade privatiseringar inom sjukvården i både Sverige, Tjeckien och Polen illustrerar hur eleganta teoretiska modeller för privatisering kan vara svåra att omsätta i praktisk verklighet. I alla tre länderna tillhandahölls sjukvård innan 1980-talets slut nästan helt genom den offentliga sektorn. Det svenska fallet är ett exempel på hur privatisering introduceras i ett västerländskt sjuvårdssystem av s.k. skattefinansierad typ, dock utan att systemets finansieringsstruktur överges. I de två forna kommunistländerna Tjeckien och Polen inbegrep privatiseringssträvandena mer omfattande förändringar genom att man samtidigt sökte ersätta de tidigare, skattefinansierade systemen med försäkringsbaserade system av kontinentaleuropeisk typ. I Tjeckien inleddes privatiseringsreformerna med en «big bang", medan reformprocessen i Polen varit mer utdragen. Trots olika grundförutsättningar för privatisering i de tre länderna finns påfallande gemensamma erfarenheter vad beträffar svårigheterna att stimulera ökningen av privata aktörer inom systemen samtidigt som den politiska kontrollen över kostnadsutveckling och resursfördelning bibehålls. I artikelns avslutande del förs en diskussion om betydelsen av offentliga regelsystemen och statlig s.k. beställarkompetens för att privatiseringar inom vården inte skall få oönskade effekter. En övergripande slutsats i artikeln är att privatiseringar inom sjukvården paradoxalt nog förefaller kräva en vidareutveckling också av statens roll. 


\section{Privatisering av offentliga tjänster: definitioner och begrepp}

"Privatisering" är ett mångtydligt begrepp som används på olika sätt, vilket ger upphov till en stundtals förvirrad debatt om dess för- och nackdelar. I sin snävaste och mest ursprungliga betydelse avser privatisering avyttring av offentlig egendom till ickeoffentliga aktörer, dvs. att exempelvis fastigheter eller kapitalvaror säljs av staten. Inom sjukvården är detta mindre vanligt. Oftare förekommande är att driften av en verksamhet överlåts från offentliga aktörer till icke-offentliga, medan lokaler och utrustning förblir i statens ägo. ${ }^{2}$ Ett annat tillvägagångssätt är att privata aktörer tilllåts etablera sig som alternativ till den offentliga vården, vilket kan leda till att denna gradvis minskar i relativ omfattning. En bredare definition av begreppet privatisering, som fångar in även sådana fenomen, är att det handlar om ett överförande av aktiviteter som tidigare varit den offentliga sektorns ansvar till privata, eller ickeoffentliga, aktörer (Savas 1987). Privatisering anger alltså riktningen på en förändringsprocess, men säger ingenting om hur omfattande förändringen är, eller hur fort den genomförs. Eftersom de flesta offentliga verksamheter redan inbegriper något element av privat karaktär bör privatisering alltså främst förstås som en relativ förändring i förhållandet mellan offentliga och privata inslag, där den senare vinner insteg $\mathrm{i}$

2 "Staten« syftar här på aktörer på statlig, regional och lokal nivå. förhållande till den förra (Lundqvist 2001, s. 256). Privatisering kan vara resultatet av ett medvetet politiskt beslut, men också ske spontant, t.ex. när frivilligt socialt arbete ökar i omfattning för att komplettera eller överta offentliga uppgifter. I den här artiklen behandlas främst den förra kategorin, som alltså handlar om politiska reformer med uttalat syfte att öka inslaget av privat verksamhet inom exempelvis sjukvården.

Nästa fråga är vad som privatiseras, eller exakt vilka aktiviteter som skall överföras till den privata sektorn. Skiljelinjen mellan offentligt och privat är i praktiken sällan tydlig, utan de flesta verksamheter utgör en blandning. Exempel från sjukvårdens område är den privata läkemedelsindustri som förser offentliga vårdgivare med mediciner och dessutom ofta finansierar en stor del av den forskning som bedrivs vid sjukhusen, förekomsten av »hyrläkare» på landstingens vårdcentraler, offentliga subventioner av vård inom den privata vårdsektorn, eller utländska patienter som behandlas mot full egenbetalning och därmed utgör en privat finansieringskälla för offentliga vårdgivare.

Denna komplexitet till trots kan det finnas anledning att analytiskt försöka skilja på "privat" och "offentligt" och därmed kunna studera privatiseringsprocesser, eftersom sådana i de flesta fall trots allt innebär förändringar av produktions- och anställningsförhållanden såväl som förutsättningarna för konsumtion eller tillgång till tjänster. Ett överförande av verksamheter till den privata sektorn innebär oftast att sättet att styra en samhällssektor från offentliga myndigheters sida blir annorlunda, och i vissa fall även att makt överförs till aktörer som står utanför deras direkta kontroll. Inom privat 
verksamhet finns också ofta drivkrafter som är av annat slag än inom offentlig verksamhet, som vinstmotiv eller idémässiga övertygelser av exempelvis religiös eller antroposofisk karaktär. Slutligen är privatisering ett intressant fenomen att undersöka därför att det avspeglar en politisk vilja att förändra innehållet $i$ en verksamhet. Till grund för detta finns en föreställning (som kan vara sann eller falsk) om icke-offentliga aktörer som på något sätt annorlunda och mer lämpade för en viss uppgift. Därför avspeglar privatisering i de flesta fall en ideologisk förändring, som i sin tur kan tyda på maktförskjutningar inom idé- eller kunskapsproduktionen i ett samhälle. $^{3}$

En vanlig distinktion i samband med privatiseringar är att skilja på privatisering av produktion och finansiering. Produktion avser den faktiska verksamheten, i detta fall att tillhandahålla vård, vilket kan ske vid vårdcentraler, sjukhus och vårdhem av olika slag samt enskilda mottagningar som drivs av läkare eller andra vårdprofessioner. Tillvägagångssätten när privata producenter ersätter offentliga kan variera, men vanliga former är nyetablering av privata aktörer, utförsäljning, avknoppning, entreprenadförfarande och ombildning av offentliga produktionsenheter till offentliga bolag. ${ }^{4}$ Privatisering

3 Dettagäller givetvis också förändringar i motsatt riktning, då staten ökar sitt verksamhetsområde på bekostnad av privata aktörer såsom skedde $\mathrm{i}$ många länder i Europa under 1900-talet.

4 I Sverige räknas rent statistiskt offentliga bolag oftast till privat verksamhet eftersom de verkar under aktiebolagslagen, trots att ägarmajoriteten utgörs av exempelvis kommun eller landsting. av finansieringen, eller betalningen, av sjukvård innebär att medborgarna själva, antingen direkt eller genom privata sjukförsäkringar, kommer att bekosta en större andel av den vård de nyttjar. I så fall minskar andelen resurser som kan fördelas mellan olika medborgargrupper enligt solidariska principer och tillgången till vård blir i högre utsträckning beroende av individens betalningsförmåga. Om privatiseringen av finansieringen är långtgående och den offentliga vårdens resurser krymper markant, riskerar vissa grupper att utestängas från vård de behöver men inte själva kan betala för. Av politiska och humana skäl är därför en omfattande privatisering av vårdens finansiering inte aktuell i de flesta länder, särskilt inte i Europa med sin väl förankrade tradition av universella, eller allomfattande, sjukvårdsystem. Däremot förs i många europeiska länder idag en diskussion om huruvida man av kostnadsskäl något borde öka inslaget av privat finansiering inom vården. Detta kan exempelvis ske genom att prioritera bort vissa medicinskt mindre essentiella tjänster bland de som tillhandahålls inom det offentliga systemet, vilket torde leda till att åtminstone vissa grupper istället bekostar dem med egna medel eller genom kompletterande privata sjukförsäkringar. Ett annat sätt att öka den privata finansieringen av sjukvården $\mathrm{i}$ ett land är att höja patientavgifterna.

Den vanligaste privatiseringsformen består alltså $\mathrm{i}$ att finansieringen även fortsättningsvis sker med till övervägande del offentliga medel, men att delar av produktionen övergår $\mathrm{i}$ privat regi. Det är främst denna form av privatise- 
ring som fortsättningsvis kommer att behandlas i artikeln. ${ }^{5}$

\section{Privatisering och produktionen av sjukvård}

Vårdproducenter inom ett sjukvårdsystem tillhandahåller olika typer av medicinska tjänster, varav den vanligaste åtskillnaden görs mellan primärvård, öppen specialistvård och sluten, eller sjukhusbaserad vård. I många västländer, dock inte Sverige, har förekomsten av privata vårdgivare varit

5 Ibland talas också om privatisering av regleringen av en verksamhet (se exempelvis Lundqvist 2001). Det innebär att den offentliga sektorn minskar sin kontroll genom att ge privata aktörer större utrymme att utforma verksamheten. Ibland kan detta ske genom att en viss bestämd aktör får i uppdrag att utforma regler för ett område. Ett exempel är när professionella grupper får styra examinering eller legitimering av nytillträdande i yrket. I andra fall handlar det om att minska det offentliga regelstyret och ge större utrymme för andra aktörer att agera fritt. Det senare fenomenet refereras oftare till som avreglering, medan överförandet av regleringsmakt till vissa bestämda privata aktörer som på så sätt kommer att överta vissa monopolfunktioner från staten brukar benämnas korporatism. En annan typ av fenomen som kan ses som en privatisering av reglerande verksamhet är att låta brukarna påverka fördelningen av offentliga resurser inom en verksamhet genom sitt val av tjänsteproducenter. Denna typ av reform, som kan begränsas till offentliga producenter, brukar dock refereras till som införande av valfrihet, eller "pengsystem". I den fortsatta framställningen kommer begreppet privatisering främst referera till privatisering av produktion eller finansiering. betydligt högre inom den öppna vården än den slutna. De vanligaste formerna i vilka privata vårdgivare uppträder är som egenföretagare med enskild mottagning, vinstsyftande företag, personalkooperativ, samt ideella organisationer eller stiftelser.

Att privatisera sjukvårdsproduktion samtidigt som finansieringen är fortsatt offentlig innebär att någon typ av överenskommelse måste ingås mellan offentliga finansiärer och privata vårdgivare om vilka tjänster som skall utföras och till vilket pris. Vilken offentlig aktör som agerar "finansiär", och alltså ingår överenskommelser, eller kontrakt, med de privata vårdgivarna, skiftar beroende på sjukvårdssystemets karaktär. I skattebaserade system, som det svenska eller brittiska, företräds staten vanligen av regionala sjukvårdsmyndigheter. I den andra huvudtyp som finns företrädd inom Europa, försäkringsbaserade system, fördelas de offentliga medlen (vanligen bestående av arbetsgivaravgifter i kombination med statliga bidrag) till regionalt baserade sjukkassor, som i sin tur ingår överenskommelser med både privata och offentliga vårdgivare inom sitt område. Inom sådana system, som till skillnad från de skattebaserade även tidigare byggt på en åtskillnad mellan de som producerar vården och de som agerar finansiärer, är andelen privata vårdproducenter ofta betydligt högre (Freeman 2000).

Av särskilt intresse i samband med privatisering är de s.k. ersättningssystemen, som bestämmer vilkoren för hur de privata vårdgivarna betalas för sina tjänster. Eftersom sjukvård är en tjänst där behoven inte kan beräknas exakt på förhand är dessa ofta utformade så att volym och ersättning 
kan ske löpande, samtidigt som ett intresse finns hos finansiären att kunna beräkna kostnaden på förhand. Vanligt är att olika typer av vårdgivare har olika ersättningssystem. Primärvårdsläkare kan antingen ersättas löpande för utförda behandlingar eller, om ett listningssystem för patienter inom primärvården tillämpas, med en viss fast summa per listad patient (s.k. kapitering). Löpande ersättning i efterhand för utförd behandling är inom litteraturen känt som fee-for-service (FFS) system. Specialister inom öppenvården, där listning inte är tilllämpligt ersätts oftast enligt denna princip. Den har fördelen av total flexibilitet och stimulerar dessutom till hög produktivitet (många behandlingar), men ger finansiären sämre möjligheter att kontrollera resursåtgången inom systemet. För institutionella vårdgivare, dvs. sjukhus och sjukhem av olika slag, finns en motsvarighet till FFS som beräknas på antal dygn en patient vårdats, s.k. per-diemersättning.

Andra sätt att ersätta vårdinstitutioner, som generellt har högre andel fasta kostnader, är genom budgetförfarande, vilket innebär att dessa på förhand ges en fast "klumpsumma» för en given period (vanligen beräknad på grundval av tidigare kostnader). Ett mer komplicerat sätt, som dock har den fördelen att det ger finansiären större kontroll över hur resurserna används, är att beräkna resursåtgången på basis av olika diagnoser, där man tagit hänsyn till att vissa behandlingar generellt sett är dyrare än andra (s.k. DRG-system). Utformningen av ersättningssystem handlar i grunden om att balansera olika incitament för de privata vårdgivarna, så att deras beteende i så hög utsträckning som möjligt bidrar till de politiska målsättningarna för systemet som helhet. Ges ersättningssystemen fel utformning kan de stimulera till övervård, vilket ökar vårdkostnaderna inom systemet utan att folkhälsan förbättras i motsvarande mån, eller leda till att vissa patientgrupper, som vårdgivarna betraktar som "mindre lönsamma» väljs bort i syfte att maximera intäkterna. ${ }^{6}$ Detta fenomen är inom den hälsoekonomiska litteraturen känt som "cream-skimming", (eller att "skumma grädden av mjölken") och kan också fördyra vårdsystemet som helhet, eftersom de mest resurskrävande behandlingarna då istället måste utföras av offentliga vårdgivare.

Den stora betydelse som utformningen av ersättningssystem kommit att få i samband med privatiseringar inom sjukvården hänger samman med en delvis förändrad syn på de privata aktörernas roll i vårdsystemen. Medan de tidigare funnits inom sjukvården främst av historiska skäl, och för att de setts som naturligt komplement till staten inom detta område, kom under 1980-talet deras främsta roll att ses som skapare av konkurrens. Ett viktigt syfte med att öka deras antal, och introducera dem i system där de tidigare knappt företrätts (som det svenska) blev att skapa mer marknadsliknande förutsättningar för produktionen av sjukvård.

6 Samma ekonomiska incitament kan förstås appellera även till offentliga vårdgivare om de ersätts på motsvarande sätt. Vanligen antas dock de finansiella drivkrafterna vara starkare bland privata vårdgivare, p.g.a deras mer utsatta ekonomiska situation. Men detta beror givetvis på omständigheterna. 
I system där privata vårdgivare redan tidigare utgjort en stor andel blev just utformningen av nya ersättningssystem för att stimulera ökad konkurrens ett viktigt led i att nå detta mål (Freeman \& Moran 2000). Grunden för det nya synsätt som placerade skapandet av konkurrens mellan vårdgivare $i$ centrum för de politiska diskussionerna om sjukvårdens framtid var idéer som utvecklats av ekonomer i USA. Senare kända under beteckningen "managed competition", eller, på svenska, "reglerad konkurrens» kom de att få ett stort inflytande på utformningen av vårdreformer i både Öst- och Västeuropa under 1990-talet, särskilt när det gällde de privata aktörernas roll.

\section{Konkurrens mellan vårdproducenter inom offentliga sjukvårdssystem: reglerad konkurrens}

Idéerna om reglerad konkurrens, främst utvecklade av den amerikanske ekonomen Alain Enthoven, gick till en början ut på att skapa ett gemensamt, offentligt reglerat sjukvårdssystem i USA inom vilket de företrädelsevis privata vårdgivarna kunde konkurrera på marknadsmässiga vilkor. Under 1970-talet sågs bristen på en allomfattande sjukförsäkring i USA som ett stort problem, samtidigt som det existerande systemet, som lämnade en stor del av befolkningen oförsäkrad, ständigt konsumerade mer resurser (Marmor 1983). Enthoven ansåg att det centrala problemet var det sätt på vilket vårdgivarna ersattes ekonomiskt av de privata försäkringsgivare som fanns representerade i landet. Detta skedde på basis av ett "fee-for-servicesystem", som garanterade alla legitimerade vårdgivare full ersättning från patienternas respektive försäkringsbolag för utförda behandlingar enligt en fast taxa. ${ }^{7}$

Enthoven konstaterade att detta system, vars tillkomst i hög grad påverkats av den starka amerikanska läkarkåren, lämnade försäkringsgivarna helt utan möjlighet att styra kostnaderna eller ens bedöma om de var rimliga. Samtidigt som vårdgivarna hade starka ekonomiska incitament att erbjuda hur mycket vård som helst, hade inte heller patienterna någon anledning att fundera över kostnaderna, eftersom de dels måste lita till läkarna när det gällde vilken behandling som behövdes, och dels inte själva betalade räkningen. I detta system, där heller ingen priskonkurrens rådde eftersom ersättningarnas storlek var bestämd på förhand, fanns alltså mycket små möjligheter att styra resursåtgång och fördelning, för någon aktör (Enthoven 1978). Enthovens lösning var att utmana vad som i praktiken var vårdgivarnas dominerande position inom systemet och skapa incitament för dessa att väga behandlingarnas effektivitet mot kostnaderna; något som han och andra ekonomer menade endast skulle ske om vårdproducenterna tvingades konkurrera med varandra på basis av priset för de behandlingar de utförde. Detta kunde i sin tur ske endast om försäkringsgivarna (inklusive staten, som i USA bekostar vården för vissa

7 I praktiken fungerar det ofta så att patienten själv först betalar vårdgivare, sedan får ersättning av sitt försäkringsbolag. 
utsatta grupper) gavs rätt att inte behöva ersätta alla vårdgivare, utan kunde ingå särskilda kontrakt med dem som erbjöd de mest konkurrenskraftiga priserna. Då, och endast då, menade han, kunde försäkringsgivarna, och i förlängningen också deras kunder, återta något av makten i systemet och därmed även tvinga fram en effektivisering av vårdproduktionen.

Eftersom skapandet av en gemensam sjukvårdsförsäkring för det amerikanska folket var en viktig del i Enthovens plan utvecklade han i sina publikationer också en modell som, i likhet med europeiska försäkringssystem, byggde på obligatoriska arbetsgivaravgifter som fördelades till olika försäkringsgivare. Till skillnad från de europeiska systemen, där tillhörighet till försäkringskassa vanligen styrs genom anställning, ansåg dock Enthoven det viktigt att medborgarna själva skulle välja försäkringsgivare, så att konkurrens kunde skapas även bland dessa. Försäkringsgivarna skulle då få konkurrera om klienter på basis av sina avgifter, även om alla var tvungna att erbjuda samma, politiskt fastställda »baspacket« av vårdtjänster och inte hade rätt att neka någon försäkring. För att skapa rättvisa förutsättningar för konkurrens mellan försäkringsgivarna, som alltså kunde välja att knyta olika vårdgivare till sig och därmed skapa interna små vårdsystem, skulle medborgare som representerade olika ekonomiska risker i egenskap av ålder, sjukdomshistoria, etc., kopplas till olika storlek på den summa de förde med sig från det offentliga fördelningssystemet till den valda försäkringsgivaren (Enthoven 1978, 1988). Idén om integrerade små vårdsystem baserade på kontrakt mellan försäkringsgivare och vårdproducenter, som av Enthoven kallades »health plans», byggde på liknade organisationer som spontant hade börjat växa fram i USA under 1970-talet, de s.k. HMOs eller Health Maintenance Organizations. Denna typ av kontraktsbaserade mini-vårdsystem inom det amerikanska sjukvårdssystemet är också kända under beteckningen »managed care».

Den reglerade-konkurrensmodellen omsattes aldrig i praktiken i USA, trots att den senare kom att ligga till grund för den s.k. Clinton-planen, som röstades ned av den amerikanska kongressen 1994. Den kom dock att få stort inflytande inom den akademiska debatt om konstruktionen av sjukvårdssystem som hade börjat föras bland framförallt ekonomer i slutet av 70-talet (Stone 1997). Den utvecklades senare till en mer allmängiltig uppsättning principer för organisationen av offentliga vårdssystem och kunde därmed tillämpas både inom försäkrings- och skattebaserade system även i Europa. Principerna är i korthet:

- Att alla medborgare garanteras tillgång till vård genom ett offentligt reglerat system, där gemensamma resurser fördelas mellan fristående, konkurrerande vårdfinansiärer på basis av antalet anslutna förmånstagare.

- Att vårdgivare tvingas priskonkurrera om att få ingå kontrakt med vårdfinansiärerna, vare sig dessa är regionala myndigheter, försäkringskassor eller vinstdrivande företag och att endast kontraktanslutna vårdgivare ersätts ekonomiskt. 
- Att vårdproducenterna helst bör vara privata och verksamheten bedrivas i enlighet med företagsekonomiska principer (eftersom detta ger största effektivitet i resursanvändningen).

- Att ersättningssystemen i så hög utsträckning som är möjligt utformas på basis av på förhand fastställda taxor för diagnoser, snarare än utförda behandlingar, eftersom detta gör att vårdgivaren måste väga behandlingens effektivitet mot kostnaden. ${ }^{8}$

Tillämpningen av principerna har av Enthoven själv getts olika utformning i försäkrings- och skattebaserade system. I det senare fallet skedde detta genom en rapport författad i Storbrittaninen 1985, då Enthoven blivit inbjuden för att bidraga till diskussionen om det brittiska sjukvårdssystemets framtid. Det förslag han utformade byggde på ett bevarande av den skattebaserade finansieringsstrukturen och de lokala myndigheternas roll som förvaltare av systemet, eftersom han insåg att detta var mer politiskt gångbart. För att trots detta skapa konkurrens bland vårdgivarna och inleda en privatisering åtminstone av produktionen av sjukvård, föreslog han att myndigheterna skulle fråntas sitt direkta ansvar för vårdproduktionen och istället agera i rollen som finansiärer och uppköpare av vård för de i regionen boende medborgarnas räkning (Enthoven 1985). Vårdproducenterna, dvs. främst sjukhus och specialistmottagningar, skulle samtidigt

8 Detta är en sammanfattande förenkling. För en fullständig överblick av principerna i reglerad konkurrens, se Enthoven 1988. omvandlas till självstyrande, marknadsmässigt agerande företag som skulle konkurrera med varandra och privata vårdgivare om att ingå kontrakt med uppköparna. På sikt skulle de också kunna säljas och därmed fullborda sin omvandling ut till marknadsbaserade privata aktörer.

Den föreslagna modellen, som kom att starkt prägla reformeringen av den brittiska sjukvården efter 1990, kallades av Enthoven för Interna marknader (Internal markets) och sågs av honom som en anpassning av reglerad konkurrens till andra traditioner och politiska förhållanden än USAs. Även när han senare skulle komma att diskutera tillämpningen av reglerad konkurrens till försäkringsbaserade system i Europa insåg han behovet av sådan politisk anpassning, t.ex. genom att många av de försäkringskassor som skulle konkurrera i praktiken var nära sammankopplade med staten och att det offentligt finansierade "baspaket" av tjänster han förespråkade blev betydligt mer omfattande än han själv ansåg nödvändigt (Enthoven 1988).

Genom den reglerad-konkurrensmodellen gjordes privatisering och marknadsbaserad konkurrens, som tidigare ansetts stå i motsats till offentligt styrda vårdssystem, till medel för att bevara just de politiska målsättningar som dessa byggde på, dvs. solidaritet och kontroll över resursanvändningen. I Europa liksom USA hade under 1980-talet de ständigt stigande sjukvårdskostnaderna kommit att ses som ett allvarligt samhällsekonomiskt problem och ett hot mot de offentliga sjukvårdssystemens framtid. Att Enthoven talade om effektivisering av produktionen, snarare än kostnadskontroll inom systemet 
som helhet, var ett faktum som gick många förbi. ${ }^{9}$

Enthovens idéer utvecklades givetvis inte i ett vacuum, utan speglar det nya synsätt som under samma tid växte fram inom den gren av nationalekonomin som sysslar med produktion av offentliga tjänster (Hugemark 1994). Utmärkande för detta var föreställningen att den offentliga sektorns monopol måste avskaffas och att verksamheten även inom dessa områden skulle bedrivas under marknadsmässiga betingelser. Vad som utmärker Enthovens publikationer och delvis kan förklara det politiska genomslag hans idéer om reglerad konkurrens har fått, är dels det faktum att han utvecklar en modell som faktiskt handlar om offentlig styrning och finansiering av vården, dels hans tillgängliga språk och egna aktiva försök att sprida sina idéer, både genom debattartiklar och samverkan med policyexperter i olika länder (Blomqvist 2002). Att både OECD och Världsbanken kom att förespråka reglerad konkurrens som ett sätt att privatisera och marknadsorientera sjukvårdssystem bidrog också till modellens spridning (OECD 1992, Iriart

9 Enthoven ansåg själv inte att det var statens uppgift att kontrollera omfattningen av vårdkonsumtionen i ett land utan endast fastställa den grundläggande vårdnivå till vilken alla medborgare garanterades tillgång; därutöver skulle marknaden styra. Detta synsätt står emellertid i kontrast till den europeiska efterkrigstradition $i$ vilken tillgång till i stort sett all sjukvård (utom rent lyxbetonad) ansetts vara en medborgerlig rättighet. Ett sådant politiskt åtagande kräver full kontroll över åtgången av resurser inom systemet, vilket innebär offentlig reglering av i stort sett all vårdkonsumtion. et al. 2001). Nederländerna, Tyskland, Italien, Spanien, Belgien, Storbritannien och Nya Zeeland hör till de länder inom vilka sjukvårdsreformer som inspirerats av Enthovens idéer infördes under 1990-talet. Ett annat exempel är Sverige.

\section{Reglerad konkurrens och privatisering inom den svenska sjukvärden}

När idéerna om reglerad konkurrens först blev kända i Sverige var det svenska sjukvårdssystemet västvärldens kanske mest offentligt dominerade. Andelen privata vårdgivare uppgick inte till mer än några få procent, ens inom primärvården, vilket var i det närmaste internationellt unikt, och konkurrensinslaget var i stort sett obefintligt (Blomqvist \& Rothstein 2000).

Att den interna marknadsmodellen kom att vinna insteg i diskussionerna om sjukvårdens förnyelse under slutet av 1980talet berodde inte bara på modellens egen attraktion och synbara förmåga att lösa en rad olika problem i den svenska vården (låg produktivitet, stigande kostnader, oklara ansvarsförhållanden, brist på patientinflytande, för att ta några exempel) utan på att den utgjorde en utmärkt grund för politiska kompromisser. För skeptiska socialdemokrater presenterades till en början en variant där konkurrensen på »marknaderna» endast skulle involvera offentliga aktörer. Dessutom kunde modellen lanseras som en demokratisering av vården, både genom ökat patientinflytande och stärkt politisk kontroll över vårdgivarna genom beställarrollen (se exempelvis Saltman \& von Otter 1987). De 
borgerliga partierna såg samtidigt potentialen för långtgående privatiseringar, liksom den eftersträvade konsumentorientering av sjukvården som valfrihet innebar för dem. Dessa inbyggda politiska motsättningar kunde till viss del döljas genom principen om lokalt självstyre, som överlät till landstingen att utforma hur och i vilken utsträckning modellens principer skulle tillämpas i praktiken (Blomqvist 2002).

Under 1990-talets första år kom olika, lokalt utformade varianter av den interna marknadsmodellen att införas i flera landsting. De gemensamma dragen var emellertid tydliga: separation mellan finansiering och produktion (s.k. beställar/utförarmodell), utökad valfrihet både på primär- och sekundärvårdsnivå, decentralisering av budgetoch personalansvar inom produktionen så att vårdgivarna gjordes till fristående aktörer, introduktion av nya ersättningssystem och slutligen, i många fall, tillämpningen av ett upphandlingsförfarande som gjorde det möjligt för privata, inklusive vinstsyftande, aktörer att konkurrera om de offentliga beställarnas kontrakt (Anell \& Svarvar 1994). De landsting som aktivt verkade för att privatisera en ökande andel av vårdproduktionen fick draghjälp av den nytillträdda borgerliga regeringen, som introducerade fri etableringsrätt för privata specialister och den s.k. husläkarlag som utsträckte samma rätt till primärvårdsläkare. Dessa nationella lagar, som innebar ett avsteg från principen om lokalt självstyre, fastslog också att ersättningssystemet för specialister skulle vara "fee-for-service" (FFS) och för primärvårdsläkare en blandning av FFS och kapitering. Dessa gynnsamma vilkor ledde initialt till en snabb ökning av antalet privatprak- tiserande läkare i öppenvården. Bara inom primärvården ökade andelen privata läkare till över 25 procent mellan åren 1994 och 1996. Inom slutenvården växte andelen privat vård långsammare, men uppvisade efter 1993 en gradvis tillväxt, främst bland de större, vinstsyftande aktiebolagen (Blomqvist 2004). Många landsting införde också ersättningssystem till privata (även många offentliga) vårdgivare inom slutenvården som baserades på principen om i förhand fastställda summor beräknade på basis av diagnostyp, dvs. s.k. prospektiva ersättningssystem.

Under 1990-talets senare del kom dock inställningen till privatiseringar och konkurrensstimulerande styrmodeller som interna marknader att ändras inom många landsting. Flera, däribland Stockholm, hade upplevt markanta kostnadsökningar efter det att man infört ersättningssystem som belönade ökat utbud av tjänster, samtidigt som etableringen av privata specialister i kombination med patienternas ökade valfrihet gjorde att det blev svårare att styra prioriteringar och resursanvändning inom systemet (Arvidsson \& Jönsson 1997). Likande erfarenheter samt spridning av forsknings- och utvärderingsresultat som pekade på att privata aktörer generellt sett vare sig kunde sägas ha högre effektivitet $i$ sin produktion eller bättre kvalitet på tjänsterna (för en översikt av denna forskning, se exempelvis Söderström \& Lundbäck 2001) ledde till att flera landsting upphörde att aktivt verka för privatisering och $\mathrm{i}$ vissa fall t.o.m. återgick till mer traditionellt budgetförfarande (Bergman \& Dahlbäck 2001).

Inom öppenvården bidrog förändrade ersättningsregler för privata läkare till att 
ökningen av deras andel kom att bromsas upp under 1990-talets senare del. Viktigast i detta avseende var att den fria etableringsrätten upphörde efter socialdemokraternas återkomst till regeringsmakten 1994, då landstingen återfick möjligheten till kostnadskontroll genom att styra etableringen. Inom slutenvården fortsatte ökningen, främst genom att några större sjukhus övergick i privat ägo eller bolagiserades, men efter den första s.k. stopplagen år 2000 och regeringens aviserade motstånd mot vinstsyftande aktörer inom akutsjukvården framstår de privata företagens framtid inom denna del av vårdmarknaden som osäker. Även inom landstingen har märkts en tilltagande skepsis mot att öka andelen privata utförare, bland annat genom en mer restriktiv inställning till nyetableringar. År 2003 uppgick enligt beräkningar från Svenskt näringsliv kostnadsandelen för köp av vård från privata vårdgivare till 8,7 procent av landstingens totala kostnader för specialistvården. För primärvården var motsvarande siffra 12,8 procent. I båda fallen finns mycket stora regionala variationer (Svenskt näringsliv 2005).

Debatten om de privata, framförallt vinstsyftande, vårdgivarnas roll har i Sverige varit intensiv under senare år och kommit att centreras kring diskussionerna om möjligheterna att styra dessa så att deras verksamhet inte undergräver principerna i det offentliga sjukvårdssystemet. Trots en principiellt positiv hållning till ökad mångfald inom vården från regering och många landstingspolitiker uttrycks i utredningar och lagförslag en tydlig oro för att ökad förekomst av kommersiellt inriktade vårdgivare leder till en tudelad vårdmarknad, där de privata vårdgivarna kommer att stimulera framväxten av även en privat finansierad vårdmarknad för de mest köpstarka grupperna (se exempelvis Engqvist 2002 och den statliga utredningen SOU 2003:23). De senaste årens utveckling i svensk sjukvård, där nya organisationsformer och aktörer, som exempelvis kommunerna, bidragit till en ökande fragmentisering av systemet, har slutligen också kommit att aktualisera grundläggande strukturfrågor såsom ansvarsförhållanden och möjligheter till långsiktig och övergripande planering inom sjukvårdssystemet som helhet (Ansvarsutredningen SOU 2003:123).

Sammanfattningsvis kan man alltså konstatera att erfarenheterna inom svensk sjukvård efter ett decennium av marknadsexperiment och nya föreställningar om vikten av konkurrens för ökad effektivitet på vad som kan benämnas "mikronivån« i vårdproduktionen har lett till ett förnyat intresse för övergripande strukturfrågor, eller "makronivån". Lärdomen tycks vara att för att privatiseringen skall leda till önskade effekter i form av ökad effektivitet, tillgänglighet och innovation, krävs utvecklade offentliga regelsystem, där de politiska ansvarsförhållandena tydliggörs och de privata vårdgivarnas vilkor regleras så att deras verksamhet inte underminerar kostnadskontrollen och möjligheten att styra resursfördelningen inom vårdsystemet.

\section{Reglerad konkurrens i Tjeckien}

Efter kommunismens fall 1989 fanns i dåvarande Tjeckoslovakien en stor politisk 
bredvillighet för omfattande privatisering av sjukvårdssystemet. De tidigare erfarenheterna av central statlig styrning av systemet enligt sovjetisk modell var ytterst negativa. Systemet var underfinansierat, korrupt, eftersatt vad gäller teknologiskt kunnande och investeringar och slutligen högst "patientovänligt", genom total brist på patientinflytande och en kultur av opersonligt och paternalistiskt bemötande från vårdpersonalens sida (Lawson \& Nemec 2003). Andra problem handlade om strukturen inom systemet, som präglades av en överdimensionerad specialist- och sjukhusbaserad vård i förhållande till primärvården och i stort sett total avsaknad av förebyggande folkhälsovård. Detta senare problem, som är typiskt för tidigare kommunistländer, är ett problem inte minst i ljuset av att den större ohälsan i Östeuropa i förhållande till Västeuropa till stor del kan förklaras av livsstilsrelaterade faktorer såsom kost, motion, alkohol- och tobaksvanor (Saltman \& Figueras 1997).

I vad som sedermera blev Tjeckien (efter separationen från Slovakien 1993) fanns samtidigt goda förutsättningar för genomgripande politiska förändringar. Till skillnad från många andra f.d. kommunistländer byttes många byråkrater inom statsapparaten ut efter 1989, samtidigt som läkarkåren snabbt organiserade sig och blev en inflytelserik aktör inom det nybildade sjukvårdsdepartementet. 1992 introducerades med hjälp av experter och ekonomiskt bistånd från bl. a. OECD, Världsbanken och Tyskland, ett helt nytt sjukvårdssystem, modellerat efter tysk försäkringsmodell men med ett starkt inslag av konkurrens i enlighet med de principer som formulerats av Ent- hoven (som då också hade börjat diskuteras i Tyskland). Att åstadkomma en snabb privatisering bland vårdgivarna var en framträdande målsättning. Som ett resultat av detta och förmodligen också det starka inflytande som läkarkåren hade över reformernas utformning, gjordes de ekonomiska förutsättningarna för läkare som övergick till privat praktik mycket gynnsamma. Ett "fee-for-service« system för öppenvården infördes, även för primärvårdsläkare, medan sjukhusen ersattes enlig per-diemprincipen.

Finansieringen av systemet byggde på obligatoriska arbetsgivaravgifter (motsvarade 13,5 procent av lönesumman för varje anställd) som betalades in till en central statlig försäkringsfond för att därefter fördelas till fristående privata försäkringsgivare på basis av antalet förmånstagare. Systemets tidigare struktur, där vård erbjöds direkt av vårdproducenter som var en del av den offentliga byråkratin (precis som i Sverige) övergavs alltså, åtminstone enligt de nya lagarnas intentioner. Det nya systemet innebar att alla medborgare gavs rätt att fritt välja försäkringsgivare och, precis som föreskrivs av principerna i den reglerade konkurrensmodellen, var dessa tvungna att erbjuda tillgång till ett "standardpaket" av vårdtjänster. Försäkringsgivarna hade sedan att kontraktera utvalda vårdgivare för att kunna erbjuda vård till förmånstagarna (European observatory 2000). Redan efter två år (1994) hade sammanlagt 26 nya, privata försäkringsfonder startats, de flesta inriktade på vissa speciella yrkesgrupper eller, i några fall, anställda vid ett visst företag (Beckmann \& Nemec 1996). Den statliga fonden, som hade regionala underavdel- 
ningar, hade vid denna tidpunkt fortfarande ansvar för ca 70 procent av befolkningen, men syftet var att dessa gradvis skulle föras över till privata försäkringsgivare allteftersom sådana etablerades och växte.

Den tjeckiska reformen var den första i sitt slag i Östeuropa, även om många grannländer vid denna tidpunkt hade planer på likande reformer. Till en början tycktes övergången till det nya systemet gå mycket bra. Privatiseringen av både primärvården och den öppna specialistvården gick mycket snabbt på grund av de ekonomiska incitament som skapades för egenpraktiserande läkare. 1996 bedrevs i stort sett all primärvård och en dominerande del av specialistvården $\mathrm{i}$ landet $\mathrm{i}$ privat regi, medan privatiseringen av slutenvården, som av naturliga skäl är betydligt mer komplicerad, hade 1993-1994 påbörjats genom utförsäljningar (Lawson \& Nemec 2003). Processen hade förberetts genom att sjukhusen gjordes självstyrande och intäktsfinansierade, dvs. fick konkurrera med privata vårdgivare om kontrakten med försäkringskassorna.

Under andra halvan av 1990-talet gick privatiseringsprocessen i Tjeckien in i en mer problematisk fas. Det upptäcktes att det nya systemet hade en starkt kostnadsdrivande effekt genom att antalet nya privata vårdgivare och utförda behandlingar steg, trots att det redan tidigare funnits ett överutbud av läkare och vårdplatser i landet. Endast mellan 1990 och 1994 ökade kostnaderna för den tjeckiska sjukvården från 5,2 procent av BNP till 7,8 procent (European Observatory 2000, s. 25). Kostnadsstegringarna inom systemet ledde regeringen till att 1997 förändra ersättningssystemen, bland annat genom att införa kapitering på primärvårdsnivå och överge per-diem systemet inom slutenvården till förmån för fasta, förhandlade budgetar. Ett annat sätt att hejda den okontrollerade expansionen av vårdgivare och hastigt ökade vårdkonsumtionen i landet var att den statliga försäkringsfonden (VZP) avslutade många vårdkontrakt och undvek att ingå nya för att minska utbudet av vårdgivare (ibid.) Detta har delvis haft avsedd effekt i form av kostnadsåtstramningar (dagens vårdkostnad beräknas till ca 7,5 procent), men missgynnade samtidigt nyetablerade privata vårdgivare. Åtstramningarna och de avslutade kontrakten ledde också till att väntetiderna ökade och att tillgången till vård minskade för många patienter. Detta har i sin tur ökat förekomsten av privata betalningar "under bordet", s.k. "gratitude payments", eller mutor, till läkare för att få tillgång till vård. Traditionen att betala mutor för att säkra tillgång till vård är en kvarleva från det tidigare kommunistiska systemet, och uppges av Lawson och Nemec idag motsvara ca 10 procent av den totala kostnaden för den tjeckiska sjukvården (Lawson \& Nemec 2003).

Samtidigt blev utvecklingen bland de nya privata försäkrarna under 1990-talet turbulent, genom att många gick i konkurs efter kort tid medan andra slog sig samman för att överleva. För att hindra underfinansiering och konkurser förbjöd de tjeckiska myndigheterna 1994 de nya försäkringsgivarna att erbjuda vårdtjänster utöver det offentligt reglerade standardpaketet, vilket väsentligt minskade konkurrensen inom systemet. 1996 hade antalet privata försäkringsgivare krympt till åtta. Vid 1990-talets 
slut stod klart att den centrala försäkringsfonden VZP snarare än att gradvis krympa genom att privata försäkrare tog över, ökat sin andel av de försäkrade till 80 procent av landets befolkning, vilket hotade omvandla hela systemet till ett statligt försäkringsmonopol. Slutligen kom under 1990-talets andra halva privatiseringen av vårdinstitutioner att bromsas och i stort sett stanna upp helt. Andelen privata vårdplatser har sedan 1997 legat i det närmaste konstant på knappt 10 procent, efter att ha ökat kraftigt från 0,3 procent 1992 till 9,4 procent (Brusse \& Prymyla 2001, s. 29). Avstannandet av privatiseringen kan ses dels som ett resultat av bristande intresse från den privata marknaden, dels som en avtagande politisk vilja från myndigheterna, som kommit att bli mer skeptiska vad beträffar potentialen för kostnads- och kvalitetsförbättringar som ett resultat av privatisering (ibid., Lawson \& Nemec 2003).

Utvecklingen i den tjeckiska sjukvården under 1990-talet visar alltså sammanfattningsvis en initialt mycket snabb omvälvning, särskilt inom öppenvården. Samtidigt står klart att det under senare delen av decenniet kom en motreaktion från myndigheternas sida på vad som visade sig vara en kostnadsgenererande systemstruktur, där vårdgivarna fick alltför starka incitament att sälja mer vård samtidigt som patienternas tillgång ökade genom privata nyetableringar och valfrihet. Även etableringarna av privata, men offentligt finansierade, försäkringsgivare visade sig vara kostnadsdrivande, och dessutom skapa stor instabilitet, eftersom resurserna inom systemet inte räckte för att bekosta all vård som förespeglades förmånstagarna. Resul- tatet har blivit en återgång till statlig kontroll och bromsande av privatiseringsprocessen, samtidigt som läkarnas och patienternas missnöje har ökat (Czech Medical Chamber 2004).

\section{Reglerad konkurrens i Polen: en långsammare reformprocess}

Reformeringen av den polska sjukvården efter 1989 har gått $i$ betydligt långsammare takt än i grannlandet Tjeckien och präglats av politisk oenighet och svårigheter att genomföra fattade beslut. Även här blev privatisering av vårdproduktionen tidigt ett övergripande mål, men finansieringsstrukturen och graden av statlig inblandning har varit omtvistade. 1991 genomfördes en reform som i mycket påminner om den interna marknadsmodell som samtidigt introducerades i Sverige och Storbritannien. Den innebar att den tidigare statliga kontrollen över systemet ersattes av regionalt och lokalt styre, där regionala myndigheter fick rollen som uppköpare av vård från ett utbud av självständigt styrda, konkurrerande vårdgivare. Ersättningarna skulle baseras på utförda behandlingar (alltså ett FFS system) och vårdgivarna fick själva sätta priser på tjänsterna. Samtidigt uppmuntrades privatiseringar inom produktionen i syfte att skapa konkurrens. Patienterna erbjöds valfrihet bland lokala "kontrakterade" vårdgivare, samtidigt som det remisstvång som funnits $i$ det tidigare kommunistiska systemet togs bort (Aksman 2000).

Mot slutet av 1990-talet stod klart att 
de interna marknaderna inte fungerade särskilt väl, utan att de flesta vårdgivare fortfarande i praktiken styrdes direkt av regionala myndigheter (s.k. voivodships) och att "kontrakten" ingåtts främst med dessa (ibid.) Privatisering hade främst kommit $\mathrm{i}$ gång $\mathrm{i}$ öppenvården, genom att läkarna öppnade egna mottagningar, ofta medan den offentliga anställningen behölls. Detta resulterade i en ökning av antalet vårdgivare och utförda behandlingar, vilket innebar att kostnaderna i systemet steg. Polen spenderade 1999 officiellt 6,2 procent av BNP på sjukvården, att jämföras med 4,5 procent 1990 (Tymowska 2001, European Observatory 1999). Även det totala antalet sjukhus i landet ökade under perioden, trots att Polen i likhet med andra östländer anses ha en överetablering av sjukhus och att reduceringen av dessa hade varit ett av målen med sjukvårdsreformerna. 1999 hade Polen 756 sjukhus, varav 18 (av de mindre) var privata (Kozierkiewicz \& Karski 2001, s. 34). Som en del i försöken att minska dominansen av specialist- och sjukhusbaserad vård genomfördes 1993 en annan reform som placerade ansvaret för primärsjukvård hos de lokala myndigheterna (gminas). Försök gjordes också att enligt brittisk modell ge primärvårdsläkare rollen som beställare av specialistvård (s.k. GP fundholding) men detta förefaller inte ha kunnat genomföras fullt ut. Trots dessa försök att stärka primärvårdens roll tycks föreställningen bland patienterna om den kvalitativt överlägsna sjukhusvården ha levt kvar, vilket i kombination med en ökad tillgänglighet och valfrihet torde ha bidragit till kostnadsökningarna inom systemet under 1990-talet (ibid.).
1999 infördes en helt ny systemstruktur genom att även Polen tog steget över till ett försäkringsbaserat system som $i$ långa stycken likande det Tjeckiska och precis som detta var modellerat efter tysk förlaga i kombination med idéerna om reglerad konkurrens. Systemet bygger på obligatoriska arbetsgivaravgifter (9 procent av lönesumman för en anställd) som inbetalas till en central fond, för att därefter fördelas till 16 administrativt fristående regionala fonder. Förhoppningen var att därefter gradvis föra över medel till nyetablerade privata försäkringsgivare för att få tillstånd konkurrens i systemet (Tymowska 2001). 1999 års reform innehöll också tvingande lagstiftning vad gäller genomförandet av självständiga och på marknadsmässig grund styrda vårdinstitutioner inom den offentliga sektorn eftersom detta i praktiken inte kommit till stånd genom 1991 års reform. Experter och internationella biståndsgivare hoppades att införandet av den nya modellen skulle leda till att privatiseringen av vårdinstitutioner skulle ta fart och mer reell konkurrens inom systemet komma tillstånd. 1999 utgjordes andelen vårdplaster i privat regi ännu endast av 0,3 procent av det totala antalet (Kozerkiewicz \& Karski 2001, s. 34).

Under de följande åren blev uppenbart att övergången till ett konkurrensbaserat försäkringssystem var förenat med stora praktiska vårigheter, samtidigt som det folkliga och politiska motståndet mot det ökade. För patienterna kom de nya sjukförsäkringskassorna, som nu reglerade tillgången till vård genom kontrakt med vårdgivarna och dessutom sökte begränsa utbudet för att kontrollera kostnadsökningarna, att framstå som ny onödig administrativ 
nivå i systemet och ett hinder i kontakten med vårdgivarna. Genom en övergång till ersättningssystem baserade på i förhand beräknade antal behandlingar, snarare än löpande ersättning i efterskott, skapades även incitament att begränsa vårdutbudet bland vårdgivarna (Filinson et al. 2003). Det förväntade påskyndandet av privatiseringsprocessen uteblev också. Detta torde bl.a. bero på att många vårdinstitutioner var starkt nedgångna eftersom de under lång tid berövats möjligheten att göra nödvändiga investeringar i lokaler och teknik, samtidigt som kontraktsvillkor och framtida utvecklingsmöjligheter för privata vårdgivare framstod som osäkra. Många vårdinstitutioner skuldsattes också under perioden 1991-1999, eftersom de utfört fler behandlingar än de fått ekonomisk ersättning för (Tymowska 2001). 2003 konstaterade en forskargrupp att förutsättningarna för privatisering inte förbättrats alls sedan det nya försäkringssystemets införande: "/ t/he intended objective of privatization of health provision appears as remote as it was before the changes" (Filinson et al. 2003, s. 385).

År 2003, efter att den tidigare oppositionen övertagit regeringsmakten, togs det drastiska steget att avskaffa de nyetablerade regionala försäkringsfonderna. Detta innebär att det polska systemet åter befinner sig i en mycket turbulent situation, där de juridiska spelreglerna och tillgången på finansiering för vårdgivarna är osäkra. Som resultat av detta har alltfler medborgare med ekonomiska möjligheter övergått till att söka vård hos privat finansierade vårdgivare, där ersättningen betalas direkt ur fickan. Detta innebär att ett parallellt, privat, vårdsystem för de välbesuttna håller på att utvecklas i Polen, samtidigt som den fattigare befolkningen på landsbygden ofta har svårt att få tillgång till vård. Även inom det offentliga systemet förekommer privata betalningar, då som mutor, för att få tillgång till vård eller få vård av högre kvalitet. Detta var vanligt även i Polen under den kommunistiska epoken, men förefaller ha ökat, snarare än minskat, i omfattning efter att systemet reformerats under 1990-talet. 1999 bedömdes den privata andelen av systemets totala finansiering utgöra närmare 40 procent, huvuddelen inte redovisad inom den officiella statistiken. Den privata försäkringsmarknaden var emellertid ännu av högst marginell betydelse (Tymowska 2001, s. 88-93).

Sammanfattningsvis kan man alltså konstatera att privatiseringen även inom den polska sjukvården mött stora svårigheter och att det är främst inom öppenvården som den överhuvudtaget kommit till stånd. Precis som i Tjeckien ledde privatiseringen till stigande vårdkostnader som resultat av nyetableringar och ökat utbud av behandlingar, samtidigt som strukturreformer försvårades. Delvis som ett resultat av detta, men också de politiska kontroverser som i Polen präglat försöken att marknadsorientera vårdsystemet, upphävdes slutligen det nya vårdsystem som introducerats. Efter detta framstår fortsatt privatisering som ett än mer avlägset mål, åtminstone inom den offentliga reglerade vårdsektorn.

\section{Sammanfattning}

I den här artikeln har jag försökt visa att det 
trots de radikalt olika förutsättningarna finns flera gemensamma nämnare i historierna om hur man under 1990-talet sökt öka andelen privata vårdgivare i Sverige, Tjeckien och Polen. Den främsta av dessa är att den ökade andelen privata vårdgivare, $\mathrm{i}$ kombination med valda ersättningssystem (som åtminstone i början baserades till stor del på löpande ersättning "i efterskott" snarare än s.k. prospektiva system) visade sig resultera i kostnadsökningar. Vilket i sin tur ledde till politiska bakslag, eftersom många hade föranletts att tro att konkurrens automatiskt skulle generera kostnadsminskningar eller åtminstone mer vård till samma kostnader. Kopplingen mellan privatisering och ökade kostnader i de här redovisade fallen kan ses som ett naturligt resultat av att nyetableringar stimuleras genom gynnsamma ekonomiska vilkor samtidigt som offentliga vårdinstitutioner av politiska skäl svårligen kan läggas ned (och läkare i många fall arbetar på båda, vilket inte är ovanligt heller inom den svenska sjukvården). Pågående konkurrens och återkommande upphandlingar innebär dessutom i sig att ett visst överutbud måste finnas på vårdmarknaden. Denna kostnadsdrivande logik späds, som vi sett i alla tre fallen, på ytterligare om valfriheten för patienterna samtidigt utökas, särskilt i frånvaro av remisstvång. Givet att mänsklighetens vårdbehov kan ses som oändliga och med en inneboende expansiv dynamik, tenderar ett ökat vårdutbud alltid att leda till ökad konsumtion och därmed ökade kostnader.

När offentliga finansiärer $i$ ett senare skede söker bromsa denna ökning, skapad av ekonomiskt motiverade vårdgivare i allians med oroliga patienter, blir de lätt impopu- lära, som både den politiska utvecklingen i Polen och debatten om vårdköerna i Sverige tydligt visar. Privatiseringar av vårdutbudet tycks alltså lätt kunna leda till överdrivna förväntningar, både bland politiker och patienter, som sedan inte kan realiseras p.g.a. att systemet ju inte tillförs några egentliga finansiella resurser och därför även fortsättningsvis måste begränsa sitt utbud.

En annan svårighet vad beträffar privatiseringar som åskådliggjorts $\mathrm{i}$ alla tre beskrivna fallen är den förtroendebrist som lätt uppstår mellan privata vårdgivare och offentliga vårduppköpare i ett reformskede. De potentiella privata investerarna vågar inte lita på att de skall tillåtas konkurrera fritt med de offentliga vårdgivarna och drar sig därför för att satsa kapital. De korta kontraktstiderna (i Sverige vanligen 2-4 år, men i Polen och Tjeckien inte sällan betydligt kortare) bidrar till osäkerheten i de privata vårdgivarnas framtid. De offentliga uppköparna vågar - likaledes ofta på goda grunder - å sin sida inte lita på att de privata vårdgivarna kommer att finnas kvar (dvs. inte gå i konkurs) och kunna tillhandahålla den vård som överenskommits. De finner det därför ofta säkrare, inte minst mot bakgrund för sitt politiska ansvar för att vården skall fungera, att lita till väl inarbetade offentliga institutioner även om dessa kanske inte är lika innovationsbenägna. Givet denna incitamentstruktur är det inte svårt att förstå att en snabb privatisering av framförallt den slutna vården haft svårt att komma till stånd i någon av länderna. Det ömsesidiga förtroende mellan offentliga finansiärer och vårdgivare som behövs för stabil, högkvalitativ produktion i privat regi kräver av 
allt att döma både tid och fasta regelverk för att utvecklas. Även detta motverkas i någon mån av kraven på priskonkurrens och fortgående effektiviseringar, eftersom det förutsätter begränsade kontraktstider och en rörlig marknad.

Sammanfattningsvis kan man konstatera att erfarenheterna av privatiseringar inom sjukvården $\mathrm{i}$ alla tre länderna pekar mot att balansgången mellan ökad konkurrens och produktivitet (dvs. ökat utbud av vårdtjänster) genom fler privata aktörer å ena sidan, och bibehållen offentlig kontroll över resursfördelningen å den andra, är mycket svår. Uppmuntras nyetableringar av privata vårdgivare genom förmånliga ekonomiska villkor, blir resultatet lätt ökad vårdkonsumtion och stigande kostnader. När offentliga myndigheter försöker korrigera denna effekt genom åtstramningar och förändringar i ersättningssystemen för de privata aktörerna skapas osäkerhet och misstroende, samtidigt som patienternas utökade valfrihet inskränks och vårdköerna riskerar att växa. Att "handla upp» sjukvårdstjänster på basis av kontrakt med fristående vårdgivare ställer samtidigt helt nya krav på regionala eller lokala offentliga sjukvårdsmyndigheter. Mycket tyder på att den osäkerhet och långsamhet som funnits i utvecklingen mot ökad andel privata vårdgivare beror på att politiker och tjänstemän inte givits tillräckligt med tid och resurser för att kunna anpassa sig till denna nya roll. Då ökar risken att man istället väljer att förlita sig på »egna» vårdproducenter inom det offentliga systemet, där inarbetare rutiner för resursfördelning och styrning funnits sedan tidigare.

I de forna kommunistländerna Tjeckien och Polen, där offentliga myndigheter efter kommunismens fall ställts inför en total omvandlig av både samhälle och ekonomi är det än mindre förvånande att lokala politiker och tjänstemän inom sjukvården visat en ovilja att frångå tidigare rutiner och nätverk för att få vården att fungera till förmån för kontrakt med nya, privata, vårdgivare. Även här handlar privatisering alltså om att utveckla kompetens och införa nya arbetsoch tänkesätt inom staten, inte minst på den lokala nivån. Att endast införa nya rättigheter för privata vårdgivare att etablera sig och konkurrera om kontrakt tycks inte tillräckligt; för utvecklandet av den ytterligt komplicerade form av "marknad» som ett offentligt finansierat sjukvårdssystem med konkurrensutsatt produktion är, krävs också en utvecklad och i väsentliga stycken förnyad statsmakt.

\section{Referenser}

Aksman, Eva (2000) "The early experience of Poland in introducing a quasi-market in health care", Eurohealth, vol. 6, no.2, s.19-21.

Anell, Anders \& Svarvar, Patrik (1994) Landstingens förnyelse av organisation och styrsystem - är strategierna samordnade? Arbetsrapport
1994:8 från IHE. Lund: IHE.

Arvidsson, Göran \& Jönsson, Bengt (1997) Politik och Marknad i framtidens sjukvaird. Stockholm: SNS Förlag.

Beckmann, Michael \& Nemec, Juri (1996) »Health Care Systems in Transition in Eastern Europe:

Paula Blomqvist: Privatisering av sjukvård: politisk lösning eller komplikation? 
The Czech Case", i Powell, Walter \& Wessen, Albert (red.), Health Care Systems in Transition: An International Perspective. London: Sage.

Bergman, Sven-Eric \& Dahlbäck, Ulla (2001) Ersättningsmodeller: en kartläggning inom hälso- och sjukvården. Rapport, Centrum för hälso- och sjukvårdsanalys, Göteborg.

Blomqvist, Paula (2004) »The Choice Revolution. Privatization of Swedish Social Services in the 1990s", Social Policy and Administration, vol.38, no. 2, s. 139-55.

Blomqvist, Paula (2002) Ideas and Policy Convergence: Health Care Reforms in the Netherlands and Sweden in the 1990s. Avhandling, Department of Political Science, Columbia University.

Blomqvist, Paula \& Rothstein, Bo (2000) Välfärdsstatens nya ansikte. Demokrati och marknadsreformer inom den offentliga sektorn. Stockholm: Agora.

Brusse, Reinhard \& Prymala, Roman (2001) »Implementing hospital reforms in the Czech Republic", Eurohealth, vol. 7, no. 3, s. 29-31.

Czech Medical Chamber (2004) Basic Information on Health Care in the Czech Republic. Http:// www.lkcr.cz (den 4 augusti 2004).

Engqvist, Lars (2002) "Ge alla vård på lika villkor". Debattartikel i Svenska Dagbladet den 30 juni 2002.

Enthoven, Alan (1978) „Consumer Choice Health Plan", New England Journal of Medicine, vol. 298, s. 650-58 och 709-20.

Enthoven, Alan (1985) Reflections on the Management of the National Health Service. Occasional Papers 5. London: Nuffield Provincial Hospitals Trust.

Enthoven, Alan (1988) Theory and Practice of Managed Competition in Health Care Finance. Amsterdam: North Holland.

European Observatory (2000) Health Care Systems in Transition: Czech Republic. London: WHO Regional Office for Europe.

European Observatory (1999) Health Care Systems in Transition: Poland. London: WHO Regional Office for Europe.

Filinson, Rachel, Chmielewski, Piotr \& Niklas,
Darek (2003) "Back to the Future: Polish Health Care Reform", Communist and Post-Communist Studies, vol.36, s. 385-403.

Freeman, Richard \& Moran, Michael (2000) "Reforming health care in Europé», West European Politics, vol. 23, no. 2, s. 35-58.

Hugemark, Agneta (1994) Den fängslande marknaden. Lund: Arkiv.

Kozierkiewicz, Adam \& Karski, Jerzy (2001) „Hospital Sector Reform in Poland", Eurohealth, vol. 7, no. 3, s. 32-35.

Lawson, Colin \& Nemec, Juri (2003) »The Political Economy of Slovak and Czech Health Policy: 1989-2000«, International Political Science Review, vol. 24, no. 2, s. 219-235.

Lundqvist, Lennart (2001) »Privatisering - varför och varför inte?", i Rothstein, Bo (red.), Politik som organisation. Stockholm: SNS Förlag.

Marmor, Ted (1983) Political Analysis and American Health Care. New York: Cambridge University Press.

Iriart, Cecilia, Erlas, Merhy, Emerson, Waitzkin Howard (2001) "Managed care in Latin America: the new common sense in health policy reform", Social Science and Medicine, vol. 52, s. 1243-53.

OECD (1992) The Reform of Health Care Systems: A Review of Seventeen OECD Countries. Paris: OECD.

Savas, Emanuel (1987) Privatization: The Key to Better Government. New York: Chatham House.

Saltman, Richard \& Figueras, Joseph (red.) (1997). European Health Care Reform. Köpenhamn: WHO.

Saltman, Richard \& von Otter, Casten (1987) „Revitalizing Public Health Care Systems: A proposal Public Competition in Sweden", Health Policy, vol. 7.

Statens offentliga utredningar. SOU 2003:23 Vårda vården - samverkan, mångfald och rättvisa. Slutbetänkande av utredningen Vårdens ägandeformer. Stockholm: Fritzes.

Stone, Deborah (1997) "The Doctor as a Businessman: The Changing Politics of a Cultural Icon", Journal of Health Politics, Policy and Law, vol. 22, no. 2. 
Svenskt näringsliv (2005) Konkurrensutsätt den offentliga sektorn. Årsrapport, februari 2005. Stockholm: Svenskt näringsliv.

Söderström, Lars \& Lundbäck, Mattias (2001) Vin sten som drivkraft. Rapport, Svenskt näringsliv.
Tymowska, Katarzyna (2001) »Health Care Transformation in Poland", Health Policy, vol. 56, s. 85-98.

\section{Summary}

\section{Privatization in Health Care A Political Solution or Complication?}

Privatization of health services has often been portrayed as a solution to cost-generating inefficiencies and lack of consumer choice in publicly operated health care systems. In this article, the concept of privatization and its applicability within the health care sector is reviewed. Special attention is paid to ideas about privatization and competition in health care known under the label "Managed Competition", which were influential among experts and policy-makers during the 1980s and 1990s. It is argued that managed competition policies, when applied in practice, often generate contradictory political pressures between, on the one hand, stimulating competition, and, on the other, preserving cost control. The argument is illustrated empirically by short surveys of managed competition-inspired health care reforms in three countries in Europe in recent times: Sweden, the Czech Republic and Poland. It is demonstrated that despite large differences in economic and political conditions, the attempt to turn previously virtually monopolistic public systems, operating on basis of a bureaucratic logic, into more pluralistic and competitive "markets" for care provision have generated similar dilemmas. Most obvious has been the dilemma of costgenerating rises in productivity and consumer demand as the supply of private services increased. Another lesson apparently learnt in all three countries has been that privatization and competition-generating policies do not solve structural problems within a national health care system, such as too many hospitals, or lack of well-developed primary care institutions. As a result, the preoccupation with what can be called "micro-level" policies, such as stimulating productivity, has been partly replaced with a renewed interest in planning and structural reform, i.e. what could be understood as "macro-level" health policy. This shift, along with the insight that purchasing skills on part of the still-public local health authorities are essential in a managed health care market, leads to the somewhat paradoxical conclusion that privatization in health care seems to call for enhanced state capacity in order to generate desired results. 